\title{
Tindak Pidana Penganiayaan tidak tepat Sasaran dalam Perspektif Pasal 351 ayat (2) Kitab Undang-Undang Hukum Pidana dan Hukum Pidana Islam (Analisis Putusan Majelis Hakim Pengadilan Negeri Bangkalan Nomor 431/pid.b/2018/pn bkl)
}

\author{
R. Arif Muljohadi \\ Abd.Wahid \\ STAI Syaichona Moh. Cholil Bangkalan \\ STAI Syaichona Moh. Cholil Bangkalan \\ Email:arifdyfaz31@gmail.com
}

Email: Abdwahid@gmail.com

\begin{abstract}
Abstrak; The main problem in this research is regarding a persecution committed by the perpetrator as a result of being driven by emotions due to things that are not yet clear, so that what he has done results in harm to other people who do not have any problems with him. So it can be concluded that the perpetrator has committed a maltreatment on purpose but not on target.This type of research uses the library research method (Library Research), which is a technique by conducting an inventory of statutory regulations and documents, also using literature obtained from the decision of the Panel of Judges which has permanent legal force based on the decision of the Panel of Judges at the Bangkalan District Court Number: 431 / Pid.B / 2018.PN Bkl.The results of this study indicate that the technique of the criminal act of persecution either intentionally or unintentionally is an act that is prohibited in Islam. who later will get sanctions, while the sanctions obtained by the perpetrators of this criminal offense of persecution is the law of qishāsh as explained in the Nash Al-Qur'an, so that the substitute punishment for it is diyat or ta'zir. However, when viewed from the applicable law in Indonesia, the perpetrator is subject to imprisonment and a fine in accordance with Article 351 of the Criminal Code concerning maltreatment. Judging from the decision of the Panel of Judges Number 431 / Pid.B / 2018 / PN Bkl that the perpetrator is subject to imprisonment for 1 (one) year and 5 (five) months imprisonment and a case fee of Rp. 2000., (two thousand rupiah).
\end{abstract}

Keywords: persecution, not on target, sanctions, correlation. 


\section{Pendahuluan}

Manusia merupakan makhluk yang berakal budi (mampu menguasai makhluk lain), insan/orang. Manusia tidak mampu untuk hidup sendirian, manusia membutuhkan interaksi dengan makhluk lainnya agar ia bisa bertahan hidup, terutama antar sesama manusia. Manusia yang hidup secara berdampingan diyakini lebih sering untuk melakukan interaksi, dapat dicontohkan seperti dalam kehidupan bertetangga. Tetangga merupakan orang (rumah) yang rumahnya berdekatan atau bersebelahmenyebelah atau orang yang tempat tinggalnya (rumahnya) berdekatan. ${ }^{1}$ Terdapat beberapa hal yang harus dilakukan untuk tetap terjaga akan sikap dan sifat seseorang dengan baik terhadap kehidupan bertetangga, diantaranya bersikap baik kepadanya dengan tidak menyakitinya, ${ }^{2}$ bersikap toleransi terhadap tetangganya serta menjaga akan keamanan tetangganya.

Manusia dapat bertindak tidak sesuai atau bertentangan dengan watak yang dimilikinya sendiri. Manusia dapat memberontak melawan fisik, spiritual dan kebutuhan materialnya, sebab hal itu, manusia bebas untuk menjalankan kehidupannya berdasarkan keinginannya sendiri. ${ }^{3}$ Akan tetapi, bebas yang terbatas seperti halnya tidak menyakiti diri sendiri atau manusia lain terutama yang berdampingan (tetangga). Dapat menyelesaikan permasalahan-permasalahan yang timbul dalam kehidupan bertetangga, tidak mengedepankan keegoisan diri ataupun membesarkan rasa emosi dan kesal sehingga menyebabkan kericuhan dan keresahan dalam kehidupan bertetangga.

\footnotetext{
${ }^{1}$ Departemen Pendidikan dan Kebudayaan. Kamus Besar Bahasa Indonesia. Jakarta: Balai Pustaka. 1990, h. 941.

${ }^{2}$ Abu Husayin Muslim Ibn Hajjáj al-Qusyayri Al-Naisaburi, Shahíh Muslim, Juz I. Bairut: ísá al-Báby al-Halaby waa al-Syurakah. 1395/1955, h. 161. Ahmad bin Hanbal_Abu Abdullah asy-Syaibaniy. Musnad Imam Ahmad bin Hanbal, Juz III. Al-Qairah: Mu'sasah Qurtubah. T.th, h. 156. Lihat Muhammad Lutfi Abdullatif. Skripsi: Tinjauan Hukum Pidana Islam Terhadap Tindak Pidana Penganiayaan Pasal 351 Kitab Undang-Undang Hukum Pidana. Universitas Islam Negeri Sunan Gunung Djati Bandung. 2018.

${ }^{3}$ Ali Syariati. Sejarah Masa Depan. DI Yogyakarta: Karkasa Media. 2017, h. 45.
} 
Faktor yang mendukung timbulnya sebuah permasalahan dalam kehidupan bertetangga diantaranya adalah faktor perekonomian yang rendah, perbedaan strata sosial, perbedaan pendapat serta golongan. Dan diantara hal tersebut yang dapat menimbulkan perpecahan dalam kehidupan bertetangga, terutama dalam kehidupan pedesaan, akan tetapi tidak menutup kemungkinan hal itu dapat terjadi dalam tatanan kehidupan perkotaan. Kejadian yang demikian tidak jarang pula berakhir dengan adanya kekerasan atau kejahatan.

Indonesia merupakan Negara yang mengatur segala bentuk kekerasan atau kejahatan akan mendapatkan hukuman. Semua telah diatur dalam aturan yang telah ditetapkan. Segala aturan tentang tingkah laku seseorang yang dianggap menyimpang dan melanggar aturan telah dijelaskan dalam KUHP (Kitab Undang-Undang Hukum Pidana). Kejahatan-kejahatan yang kerap terjadi dalam kehidupan bertetangga adalah kejahatan berupa penganiayan, bahkan pelaku ataupun korban tidak menyadari apa yang telah terjadi tersebut merupakan sebuah tindakan yang termasuk dalam kategori penganiayaan. Penganiayaan merupakan perbuatan kejahatan sengaja atau tidak sengaja terhadap seseorang sehingga mengakibatkan cacat badan (luka ringan/luka berat) atau bahkan kematian. Delik penganiayaan dalam tatanan hukum dikategorikan sebagai kejahatan, yaitu perbuatan yang akan mendapatkan hukuman bagi para pelakunya berdasarkan KUHP yang berlaku, meskipun didalamnya tidak memuat arti mengenai penganiayaan itu sendiri.

Adapun penganiayaan berdasarkan KUHP dimuat dalam BAB XX Pasal 351 - Pasal 356, yaitu;

a. Penganiayaan biasa (Pasal 351 KUHP)

b. Penganiayaan ringan (Pasal 352 KUHP)

c. Penganiayaan berencana (Pasal 353 KUHP)

d. Penganiayaan berat (Pasal 354 KUHP)

e. Penganiayaan berat berencana (Pasal 355 KUHP) 
f. Penganiayaan terhadap orang yang berkualitas tertentu (Pasal 356 KUHP).

Dalam Islam tindak pidana yang dikemukakan oleh Abdul Qadir Audah sebagaimana yang dikutip oleh Ahmad Wardi Muslich dalam bukunya yang berjudul Hukum Pidana Islam adalah setiap perbuatan menyakiti orang lain yang mengenai badannya, tetapi tidak sampai menghilangkan nyawanya, sedangkan menurut Wahbah Zuhaili yang dikutip pula oleh Ahmad Wardi Muslich dalam bukunya yang berjudul Hukum Pidana Islam, bahwa setiap tindakan melawan hukum atas badan manusia, baik berupa pemotongan anggota badan, pelukaan, maupun pemukulan sedangkan jiwa atau nyawa dan hidupnya masih tetap tidak diganggu. Intinya tindak pidana penganiayaan adalah perbuatan menyakiti, yaitu setiap pelanggaran yang sifatnya menyakiti atau merusak anggota manusia, seperti pukulan, pencekikan, pemotongan dan penempelengan. ${ }^{4}$ Tindak pidana penganiayaan menurut Hukum Pidana Islam adalah setiap perbuatan menyakitkan yang mengenai badan seseorang, namun tidak kematian.

Dalam Islam segala bentuk pelanggaran akan ada hukuman bagi para pelakunya, hal tersebut diharapkan agar pelaku jera dan tidak mengulagi perbuatannya lagi dengan hal itu dapat menciptakan kehidupan yang tentram. Dalam Islam hukuman bagi para pelaku tindak pidana penganiayan adalah hukuman qishāsh, sebagaimana Allah Swt. berfirman:

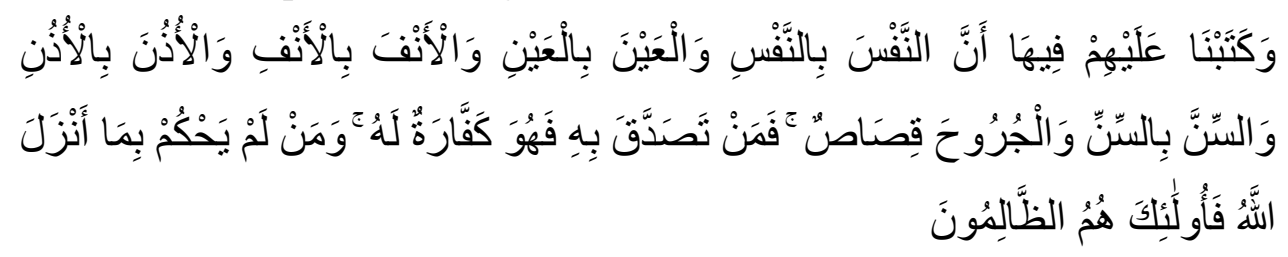

"Dan Kami telah tetapkan terhadap mereka di dalamnya (At Taurat) bahwasanya jiwa (dibalas) dengan jiwa, mata dengan mata, hidung dengan hidung, telinga dengan telinga, gigi dengan gigi, dan luka luka (pun) ada qishaashnya. Barangsiapa yang melepaskan (hak qishaash)nya,

\footnotetext{
${ }^{4}$ Ahmad Wardi Muslich. Hukum Pidana Islam. Jakarta: Sinar Grafika. 2005, h. 179.
} 
maka melepaskan hak itu (menjadi) penebus dosa baginya. Barangsiapa tidak memutuskan perkara menurut apa yang diturunkan Allah, maka mereka itu adalah orang-orang yang zalim." (QS. Al-Maidah 5:45) ${ }^{5}$

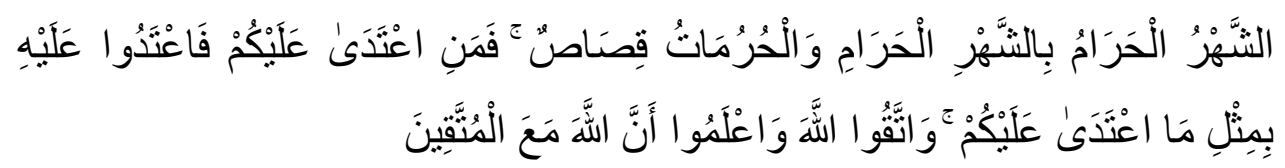

"Bulan haram dengan bulan haram, dan pada sesuatu yang patut dihormati, berlaku hukum qishaash. Oleh sebab itu barangsiapa yang menyerang kamu, maka seranglah ia, seimbang dengan serangannya terhadapmu. Bertakwalah kepada Allah dan ketahuilah, bahwa Allah beserta orang-orang yang bertakwa." (QS. Al-Baqarah 1:194)6

Penganiayaan dalam hukum positif dan hukum pidana Islam merupakan suatu kejahatan yang dilarang, karena dapat mengancam ketentraman dan ketenangan orang lain, keluarga ataupun dirinya. Dan akan ada hukuman bagi siapapun yang telah melakukannya.

Adapun kronologi kasus yang terdapat dalam putusan Majelis Hakim Pengadilan Negeri Bangkalan adalah bahwa terdakwa Moch. Tuki pada hari Selasa tanggal 09 Oktober 2018 sekitar jam 17.30 WIB akan pergi mandi lalu melihat ada beberapa orang warga sekitar melihat-lihat kedalam pekarangan rumah terdakwa yang berada di Dsn. Barangan Ds. Bunajih Kec. Labang Kab. Bangkalan melihat hal tersebut lalu terdakwa emosi, sehingga kemudian terdakwa mengambil sebilah arit sambil berjalan menghampiri beberapa orang tersebut namun saat didatanginya lalu orang-orang tersebut langsung pergi yang mana membuat sikap terdakwa menjadi bertambah emosi sehingga akhirnya terdakwa lalu menyanggong atau menunggu orang-orang yang akan melintas di jalan tersebut tersebut dengan maksud menanyakan sikap warga sekitar yang

${ }^{5}$ Shaleh Dahlan, Dkk. Asbābun Nuzūl Latar Belakang Historis Turunnya Ayat-ayat AlQuran. Diponegoro: CV. Penerbit Diponegoro. 2007, h. 192.

${ }^{6}$ Ibid 58. 
selalu memantau rumah terdakwa. Selanjutnya tidak lama kemudian sekitar jam 18.30 wib terdakwa melihat saksi korban Mojar mengendarai sepeda motor melintas dijalan tersebut dan terdakwa lalu mencoba menghentikannya namun saksi korban Mojar tetap melajukan sepeda motornya yang mana membuat terdakwa semakin emosi. Setelah itu terdakwa langsung membacokkan sebilah aritnya ke arah saksi korban Mojar hingga mengenai tangan kiri bagian lengan bawah kiri.

Akibat kejadian tersebut, Majelis Hakim memutuskan bahwa terdakwa telah melakukan tindak pidana penganiayaan yang menyebabkan luka berat dengan menjatuhkan hukuman pidan kepada terdakwa dengan pidana penjara selama 1 (satu) tahun 5 (lima) bulan dan membebankan biaya perkara sebesar Rp. 2000,00- (dua ribu rupiah) serta biaya saksi korban selama berada dalam rumah sakit ditangguhkan kepada keluarga terdakwa.

\section{Pembahasan}

\section{Tindak Pidana Tidak Tepat Sasaran dalam Hukum Pidana Islam}

Tindak pidana penganiayaan dalam hukum pidana Islam dapat dikategorikan menjadi tindak pidana atas selain jiwa (penganiayaan) dengan sengaja yaitu pelaku dengan sengaja melakukan perbuatan yang dilarang dan melawan hukum dengan maksud supaya perbuatannya itu mengenai dan menyakiti orang, dan tindak pidana atas selain jiwa (penganiayaan) secara tidak sengaja yaitu suatu perbuatan dimana pelaku sengaja melakukan suatu perbuatan, tetapi tidak ada maksud untuk menyakiti/melukai orang lain dengan melawan hukum. Jadi tindak pidana atas selain jiwa dengan tidak sengaja/kesalahan adalah pelaku memang dengan sengaja melakukan perbuatan, tetapi perbuatan tersebut sama sekali tidak dimaksudkannya untuk mengenai/melukai/menyakiti orang lain. namun kenyataannya ada korban akibat perbuatan tersebut. 
Akan tetapi menurut Syafi'iyah dan Hanabilah selain dua hal tersebut terdapat tindak pidana selain jiwa (penganiayaan) ketiga, yaitu tindak pidana atas selain jiwa (penganiayaan) menyerupai sengaja, yaitu suatu tindak pidana yang dilakukan oleh seseorang yang memukul orang lain dengan benda/apapun yang ringan namun menyebabkan orang tersebut menderita luka berat.

penganiayaan (jināyah terhadap selain jiwa) dapat dilakukan secara sengaja, semi sengaja dan kesalahan. Dalam hukum pidana Islam para ulama membagi menjadi lima macam: ${ }^{7}$

1. Ibanat al-atraf, yaitu memotong anggota badan, termasuk didalamnya pemotongan tangan, kaki, jari, hidung, gigi dan sebagainya;

2. Idzhab ma'al-athraf, yaitu menghilangkan fungsi anggota badan (anggota badan itu tetap ada tapi tidak dapat berfungsi sebagaimana mestinya), misalnya membuat korban tuli, bisu, buta dan sebagainya;

3. As-syaj, yaitu pelukaan terhadap kepala dan muka (secara khusus);

4. Al-jarh, yaitu pelukaan terhadap selain wajah dan kepala termasuk didalamnya pelukaan yang sampai kedalam perut atau rongga dada; dan

5. Pelukaan yang tidak masuk ke dalam salah satu dari empat jenis pelukaan diatas.

Tindak kejahatan dapat dikategorikan sebagai tindak kejahatan apabila telah memenuhi unsur-unsur, dalam hukum pidana Islam tindak pidana penganiayaan memiliki beberapa unsur yang bisa menyebabkan kejahatan tersebut dapat dikategorikan sebagai tindak pidana penganiayaan, diantaranya adalah secara yuridis normatif, dimana dalam satu aspek harus didasari oleh suatu dalil yang menentukan larangan terhadap perilaku tertentu dan diancam dengan hukuman.

${ }^{7}$ A. Dzajuli. Fiqh Jinayah: Upaya Menanggulangi Kejahatan dalam Islam. Jakarta: Rajawali Press. 1996, h. 146-147. 
Dalam hal ini mengandung unsur materiil, yaitu sikap yang dapat dinilai sebagai suatu pelanggaran terhadap sesuatu yang diperintahkan oleh Allah Swt. selanjutnya adalah unsur moral, yaitu kesanggupan seseorang untuk menerima sesuatu yang secara nyata mempunyai nilai yang dapat dipertanggungjawabkan, dalam hal ini seseorang yang melakukan larangan tersebut harus seorang mukallaf.

Allah Swt. mensyari'atkan 3 macam hukuman bagi siapa saja yang melakukan tindak pidana kejahatan, baik kejahatan yang menghilangkan jiwa ataupun tidak dan hal tersebut dilakukan secara sengaja ataupun tidak sengaja. Hukuman tindak pidana dalam hukum pidana Islam ini dibagi menjadi 2 bagian, yaitu hukuman pokok dan hukuman pengganti. Hukuman pokok bagi pelaku tindak pidana adalah hukuman qishāsh, sedangkan hukuman pengganti jika hukuman qishāsh terhalang atau gugur karena ada beberapa sebab adalah hukuman diyat atau ta'zir.

Qishāsh secara bahasa adalah menggunting, mendekati, menceritakan, mengikuti (jejaknya) dan membalas. Sedangkan secara istilah, Ibnu Mauzur dalam Lisān al-Arab menyebutkan suatu hukuman yang ditetapkan dengan cara mengikuti bentuk tindakan pidana yang dilakukan. ${ }^{8}$

Diyat secara bahasa adalah bila wali membunuh memberikan harta sebagai tebusan nyawa/lainnya. Sedangkan pengertian secara syari'at diyat adalah harta yang wajib dibayarkan kepada korban atau walinya karena disebabkan oleh tindak pidana terhadap jiwa atau selain jiwa. $^{9}$

Kadar hukuman diyat yang biasa menjadi patokan adalah dengan unta, untuk tindak hukuman paling berat adalah 100 ekor unta.

${ }^{8}$ Paisol Burlian. Implementasi Konsep Hukum Qishash di Indonesia. Jakarta: Sinar Grafika. 2015, h. 28.

9 Abu Malik Kamal bin As-Sayyid Salim. Shahih Fiqh Sunnah, terjemah: Abu Ihsan. H. 342 
Jika tidak dapat membayar dengan unta maka beralih pada harga unta tersebut atau dengan membayar 100 dinar atau 12.500 dirham. ${ }^{10}$

Hukuman diyat merupakan hukuman pengganti yang dilakukan apabila hukuman qishāsh tidak bisa dilaksanakan akibat sebab-sebab tertentu, hukuman qishāsh gugur dan pelaku tetap akan mendapatkan hukuman, bukan hukuman qishāsh lagi melainkan hukuman diyat. Diyat akan menjadi hukuman pengganti bagi hukuman qishāsh apabila penganiayaan yang dilakukan tersebut secara sengaja, dan apabila tindakan penganiayaan tersebut dilakukan secara menyerupai sengaja/kesalahan/kealpaan, maka hukum dari hukuman diyat ini adalah hukuman pokok.

Diyat sebagai hukuman pokok atau sebagai hukuman pengganti dapat diistilahkan dengan diyat yang penuh (kāmilah), yang artinya 100 ekor unta. Adapun diyat yang kurang dari diyat yang penuh maka dapat diistilahkan dengan istilah irsh. Irsh terbagi menjadi dua macam, yaitu irsh yaang sudah ditentukan (muqaddar), dan irsh yang belum ditentukan (ghairu muqaddar). ${ }^{11}$

Sedangkan Ta'zir menurut bahasa adalah ta'dib atau memberi pelajaran. Hukuman ta'zir adalah hukuman yang belum ditetapkan oleh syara'. Melainkan diserahkan kepada qadli (hakim), baik penentuannya maupun pelaksanaannya. ${ }^{12}$

2. Tindak Pidana Tidak Tepat Sasaran dalam Pasal 351 ayat (2) KUHP Berdasarkan Putusan Nomor 431/Pid.B/2018/PN Bkl

Berdasarkan kasus yang telah dijelaskan diatas, bahwa hal tersebut merupakan sebuah penganiayaan yang dapat dikategorikan ke dalam penganiayaan biasa yang menyebabkan luka berat. Penganiayaan biasa yang menyebabkan luka berat tersebut terdapat dalam Pasal 351 ayat (2) KUHP, hal itu sebagaimana berikut;

\footnotetext{
${ }^{10}$ Opcit, h. 597

11 Ahmad Wardi Muslich. Hukum Pidana Islam. Jakarta: Sinar Grafika. 2005, h.196.

${ }^{12}$ Oemar Sono. Hukum Hakim Pidana. Jakarta: Erlangga. 2018, h. 19.
} 


\section{Pasal 351 KUHP: ${ }^{13}$}

(1) Penganiayaan diancam dengan pidana penjara paling lama dua tahun delapan bulan atau pidana denda paling banyak empat ribu lima ratus rupiah;

(2) Jika perbuatan mengakibatkan luka-luka berat, yang bersalah diancam dengan pidana penjara paling lama lima tahun;

(3) Jika mengakibatkan kematian, diancam dengan pidana penjara paling lama tujuh tahun

(4) Dengan penganiayaan disamakan sengaja merusak kesehatan;

(5) Percobaan untuk melakukan kejahatan ini tidak dipidana.

Adapun unsur-unsur yang terkandung dalam Pasal 351

KUHP antara lain sebagai berikut:

(1) Adanya kesengajaan;

Unsur kesengajaan merupakan unsur subjektif (kesalahan).

Dalam tindak unsur kesengajaan harus diartikan sempit, yaitu kesengajaan dengan maksud (opzet alsogmerk).

Namun demikian patut menjadi cacatan, bahwa sekalipun kesengajaan dalam tindak itu bisa ditafsirkan kesengajaan dengan sadar akan kemungkinan tetapi penafsiran tersebut juga terbatas pada adanya kesengajaan sebagai kemungkinan terhadap akibat. Artinya kemungkinannnya penafsiran secara luas terhadap unsur kesengajaan itu, yaitu kesengajaan sebagai kepastian, hanya dimungkinkan terhadap akibatnya. Sementara terhadap perbuatan sendiri haruslah merupakan tujuan pelaku. Artinya perbuatan itu haruslah perbuatan yang benar-benar ditujukan oleh pelakunya sebagai perbuatan yang dikehendaki atau dimaksudkannya.

(2) Adanya perbuatan;

Unsur perbuatan merupakan unsur objektif. Perbuatan yang dimaksud adalah aktifis yang bersifat positif. Dimana manusia

${ }^{13}$ R. Soesilo. Kitab Undang-Undang Hukum Pidana Serta Komentar-Komentarnya Lengkap Pasal Demi Pasal. Bogor: Politeia. 1995, h. 244. 
menggunakan anggota tubuhnya untuk melakukan aktifitasnya sehari-hari, sedangkan sifat abstrak yang dimaksud adalah perbuatan yang mengandung sifat kekerasan fisik dalam bentuk memukul, menendang, mencubit, mengiris, membacok dan sebagainya.

(3) Adanya perbuatan (yang dituju), rasa sakit pada tubuh dan/atau luka pada tubuh;

a) Membuat perasaan tidak enak,

b) Rasa sakit pada tubuh, penderitaan yang tidak menampakkan perubahan pada tubuh,

c) Luka pada tubuh, menampakkan perubahan pada tubuh akibat terjadinya penganiayaan,

d) Merusak kesehatan orang.

(4) Akibat yang menjadi tujuan satu-satunya;

Majelis hakim memutuskan bahwa terdakwa telah dinyatakan bersalah dan terbukti telah melakukan kejahatan berupa tindak pidana penganiayaan yang dilakukan terhadap tetangganya yang sebelumnya tidak ia kenali dan ternyata korban merupakan kerabat dekatnya, hal itu sesuai dengan putusan Majelis Hakim Nomor 431/Pid.B/2018/PN Bkl. Atas tindakan yang telah ia lakukan tersebut Majelis Hakim menjatuhkan sanksi pidana terhadap terdakwa dalam bentuk pidana penjara selama 1 (satu) tahun dan 5 (lima) bulan dengan menetapkan masa penangkapan dan penahanan yang telah dijalaninya dikurangkan seluruhnya dari pidana yang dijatuhkan, tak hanya itu, terdakwa juga dibebankan membayar biaya perkara sebesar Rp. 2.000,- (dua ribu rupiah), serta biaya korban selama berada dirumah sakit yang ditangguhkan kepada pihak keluarga terdakwa. Putusan yang diucapkan oleh Majelis Hakim di Pengadilan Negeri Bangkalan ini mengacu pada aturan Pasal 351 ayat (2) KUHP. 
Dalam memberikan pertimbangannya dalam tindak pidana penganiayaan tersebut termasuk didalamnya hal-hal yang memberatkan atau meringankan terdakwa. Adapun hal-hal yang dapat memberatkan terdakwa adalah hal-hal yang berkaitan dengan akibat perbuatan yang telah dilakukan oleh terdakwa terhadap korban/saksi korban hingga mengalami luka berat pada tangan kiri bagian lengan bawah kiri dan mengharuskannya untuk dirawat di puskesmas hingga dirujuk ke rumah sakit untuk melakukan operasi pada tangannya tersebut. Fakta tersebut diperkuat dengan dilakukannya Visum oleh Dr. Edy Suharto SpF di RSUD Syarifah ambami Rato Ebu Bangkalan.

Selain tentang hal-hal yang dapat memberatkan, terdapat pula hal-hal yang dapat meringankan terdakwa dari hukuman yang seharusnya. Diantaranya adalah terdakwa menyesali perbuatannya dan berjanji untuk tidak mengulanginya lagi, terdakwa dan saksi korban sudah berdamai dan saling memaafkan, keluarga terdakwa membiayai semua biaya selama korban dirawat dirumah sakit, sehingga Majelis Hakim pun juga mempertimbangkan putusannya dengan memperhatikan terdakwa pada tuntutan yang dilakukan oleh Jaksa Penuntut Umun.

Dalam memutuskan perkaranya tersebut hakim memiliki beberapa teori yang digunakan untuk menjatuhkan putusannya, yaitu keseimbangan, yaitu antara syarat-syarat yang ditentukan oleh Undang-Undang dan kepentingan pihak-pihak yang berkaitan dengan perkara. Keseimbangan dalam praktiknya dirumuskan dalam pertimbangan mengenai hal-hal yang memberatkan dan meringankan pidana bagi terdakwa Pasal 197 ayat (1) huruf (f) KUHP. Jadi dalam hal ini hakim sudah dengan sepantasnya dan selayaknya dalam memutuskan perkara ini dengan sikap yang seimbang atau tidak berat sebelah sehingga dalam memutuskan perkara hakim dapat memutuskan dengan rasa keadilannya. 
Dalam menjalankan amanahnya, Majelis Hakim dalam memberikan pertimbangan hukumnya menyatakan bahwa apa yang telah dilakukan oleh terdakwa terhadap saksi korban sudah sesuai dengan unsur-unsur yang ada dalam unsur-unsur tindak pidana penganiayaan, sehingga dapat dinyatakan bahwa apa yang telah terjadi sesuai dengan tuntutan dari Jaksa Penuntut Umum, barang bukti serta keterangan saksi. Bahwa terdakwa dengan sah dinyatakan telah melakukan tindak pidana penganiayaan biasa yang menyebabkan luka berat sebagaimana yang terkandung dalam Pasal 351 ayat (2) KUHP. Selain itu, Majelis Hakim juga telah menjalankannya sesuai dengan prosedur yang telah ditetapkan.

\section{Korelasi Pasal 351 ayat (2) KUHP dengan Hukum Pidana Islam tentang Tindak Pidana Penganiayaan}

Tindak pidana penganiayaan tidak dijelaskan secara rinci dalam KUHP tersebut, akan tetapi hanya dijelaskan secara singkat. Sehingga dapat disimpulkan sesuai dengan keterangan yang terdapat dalam KUHP tersebut yang tepatnya dalam Pasal 351-356 KUHP Bahwa tindak pidana penganiayaan merupakan suatu perbuatan kejahatan dengan sengaja atau tidak sengaja terhadap seseorang sehingga mengakibatkan cacat badan (luka ringan/luka berat) atau bahkan kematian.

Telah dijelaskan pula dalam hukum pidana Islam bahwa tindak pidana atas selain jiwa/jināyah selain pembunuhan atau yang sering dikenal dengan sebutan tindak pidana penganiayaan adalah setiap perbuatan haram yang dilakukan terhadap anggota tubuh, baik dengan cara memotong, melukai maupun menghilangkan fungsinya, atau dalam pengertian lainnya bahwa tindak pidana penganiayaan adalah setiap perbuatan yang menyakitkan yang mengenai badan seseorang, namun tidak mengakibatkan kematian. 
Berdasarkan keterangan diatas, jelas telah dapat kita tarik kesimpulannnya bahwa tindak pidana penganiayaan baik dalam hukum positif (Pasal 351-356 KUHP) dan hukum Islam (hukum pidana Islam) memiliki hubungan yang sangat erat, dikarenakan kejahatan berupa tindak pidana penganiayaan ini sama-sama dikategorikan dalam sebuah delik kejahatan yang dapat dilakukan oleh seseorang terhadap orang lain baik secara sengaja ataupun tidak sengaja yang dapat mengancam/mencelakai orang lain, dengan apa yang telah dilakukannya tersebut tentu dapat menyakiti orang yang telah menjadi sasarannya tersebut. Tak hanya itu, mengenai apa yang telah dilakukan oleh pelaku tersebut juga dapat mengakibatkan hal-hal negatif terhadap orang-orang yang berada disekitarnya. Dapat dicontohkan seperti kasus yang telah mendapatkan putusan tetap oleh Majelis Hakim yang dipaparkan diatas, bahwa kejadian yang telah dilakukan oleh terdakwa (pelaku tindak penganiayaan) terhadap saksi korban tersebut tidak hanya merugikan saksi korbannya saja, akan tetapi ia telah menimbulkan keresahan dan ketakutan para warga sekitar, keluarga saksi korban dan juga keluarga pelaku, lebih-lebih ia akan merasakan kerugian dan penyesalan dalam dirinya sendiri akibat ulahnya tersebut.

Adapun seseorang yang telah melakukan tindak pidana penganiayaan tersebut dalam KUHP ataupun hukum pidana Islam lantas tidak akan langsung dihukumi telah melakukan perbuatan kejahatan berupa penganiayaan sebelum ia diperiksa dan telah memenuhi unsur-unsur telah melakukan tindak pidana penganiayaan. Dikarenakan sebuah tindak pidana kejahatan banyak jenis dan macamnya, tidak hanya tindak pidana penganiayaan saja, maka dari itu perbuatan tercela yang telah sangat jelas dilarang untuk tidak dilakukan itu harus menyesuaikan apa yang telah terjadi secara nyata dengan unsur-unsur yang telah ada 
ketetapannya agar orang yang telah melakukan tindak kejahatan itu bisa diberi hukuman yang pantas sesuai dengan perbuatannya dan juga dapat menimbulkan hati takut dan jera untuk tidak melakukan hal yang sama ataupun hal-hal lainnya yang dapat dikategorikan sebagai tindak pidana kejahatan kepada orang lain.

Keterkaitan antara Pasal 351 KUHP dan hukum pidana Islam juga dapat memberikan jalan untuk para Majelis Hakim dalam menentukan hukuman yang sepantasnya terhadap pelaku. Meskipun dalam negara kita tidak diberlakukan secara menyeluruh tentang hukum pidana Islam, akan tetapi hal tersebut juga dapat dijadikan tolak ukur para Majelis Hakim dalam mempertimbangkan putusannya, hal tersebut sejalan dengan apa yang telah ada dalam kenyataan yang ada dan dikarenakan pula mayoritas warga sekitar pelaku menganut agama Islam. tak hanya itu, berdasarkan penjelasannya mengenai tindak pidana penganiayaan dalam Pasal 351 KUHP dan hukum pidana Islam sangat berkaitan, baik dalam pengertiannya hingga sampai pada hukumannya.

Hal ini juga dapat membuat orang lain tidak melakukan tindak pidana penganiayaan, bahkan tindak pidana apapun karena perbuatan pidana selain dapat merugikan dirinya dan juga keluarganya bahkan siapapun yang merasa mengenalinya dapat membuat dirinya dijauhi akibat perbuatannya tersebut. Pelaku yag telah dihukum tidak hanya selesai dalam hukuman yang telah dijalaninya selama berada didunia saja, akan tetapi juga akan mendapatkan hukuman yang berbeda nantinya di akhirat apabila tidak bertaubat dengan kesungguhan hatinya dan tidak akan mengulangi perbuatan yang dilarang oleh Tuhan yang Maha Esa ataupun tindakan-tindakan lainnya yang dapat dikategorikan sebuah tindak kejahatan terhadap orang lain. 
Dengan adanya hubungan yang sangat erat tersebut, maka semua manusia harus bisa mengupayakan dirinya sendiri untuk mengendalikan hasrat dirinya untuk tidak melakukan kejahatan, melukai atau menyakiti orang lain dan mampu untuk meredam emosi serta dapat menetralkan egoismenya dalam kehidupannya.

\section{Kesimpulan}

1. Dalam Pandangan hukum pidana Islam terhadap pelaku tindak pidana penganiayaan tidak tepat sasaran dapat dikategorikan sebagaimana tindak pidana atas selain jiwa (penganiayaan). Dalam hukum pidana Islam penganiayaan yang telah dilakukan oleh pelaku tersebut termasuk dalam jenis penganiayaan dalam bagian Ibanat al-athraf, yaitu tindakan terhadap perusakan anggota badan, sebagaimana yang telah terjadi pada korban. Dengan begitu pelaku dapat menerima hukuman berupa hukuman qishāsh sebagai hukuman pokoknya, dikarenakan pelaku memang memiliki niatan untuk melukai/merugikan orang lain, akan tetapi orang yang dituju tidak tepat sasaran seperti apa yang telah diniatinya, dan pelaku bisa mendapatkan hukuman diyat bila terdapat beberapa hal yang menyebabkan hukuman qishāsh gugur.

2. Korelasi Pasal 351 ayat (2) KUHP dengan hukum pidana Islam tentang penganiayaan tidak tepat sasaran terhadap putusan majelis hakim Pengadilan Negeri Bangkalan dalam Nomor 431/Pid.B/2018/PN Bkl dapat ditemukan dari hal yang mendasar, seperti berdasarkan pengertian, jenis, serta dari sanksi. Apa yang telah diperbuat oleh pelaku, itulah yang akan ia terima nantinya sebagai hukumannya bahwa ia telah melakukan tindakan yang tidak wajar dan dapat merusak ketenangan warga atau masyarakat sekitar. Hal-hal yang berlaku terhadap pelaku yang telah tertuang dalam KUHP 
ataupun dalam hukum pidana Islam sekalipun bukanlah sebagai ajang balas dendam bagi pelaku tindak kejahatan, terutama kejahatan penganiayaan ini. Melainkan hal tersebut agar pelaku bisa sadar dan jera terhadap apa yang telah dilakukannya, serta berjanji untuk tidak akan mengulanginya lagi, juga sebagai contoh dan tolak ukur bagi masyarakat yang lainnya.

\section{Daftar Pustaka}

Burlian, Paisol. 2015. Implementasi Konsep Hukum Qishash di Indonesia. Jakarta: Sinar Grafika.

Dzajuli, A. 1996. Fiqh Jinayah: Upaya Menanggulangi Kejahatan dalam Islam. Jakarta: Rajawali Press.

Kamal, Abu Malik bin As-Sayyid Salim. Tt. Shahih Fiqh Sunnah, terjemah: Abu Ihsan.

Kebudayaan, Departemen Pendidikan. 1990. Kamus Besar Bahasa Indonesia. Jakarta: Balai Pustaka.

Ketua Mahkamah Agung RI dan Ketua Komisi Yudisial RI. 2015. Kode etik dan Pedoman Hakim. Jakarta: Komisi Yudisial RI.

Muslich, Ahmad Wardi. 2005. Hukum Pidana Islam. Jakarta: Sinar Grafika.

Pengadilan Negeri Bangkalan. 2019. Putusan Majelis Hakim Nomor 431/Pid.B/2018/PN/Bkl. Bangkalan: PN. Bangkalan

Seno, Oemar. 2018. Hukum Hakim Pidana. Jakarta: Erlangga.

Shaleh, Dahlan, Dkk. 2007. Asbābun Nuzūl Latar Belakang Historis Turunnya Ayat-ayat Al-Quran. Diponegoro: CV. Penerbit Diponegoro. 
Jurnal Keislaman, Vol 3, No 2 September

Soesilo, R. 1995. Kitab Undang-Undang Hukum Pidana Serta KomentarKomentarnya Lengkap Pasal Demi Pasal. Bogor: Politeia.

Syariati, Ali. 2017. Sejarah Masa Depan. DI Yogyakarta: Karkasa Media 